\title{
Personality Antecedents of Online Buying Impulsiveness
}

\author{
Tsai Chen and Ming-Chang Lee
}

\begin{abstract}
The hierarchical relationships of personality traits related to online buying impulsiveness were empirically examined. The results show that three elemental traits agreeableness, need for arousal, and need for material - are predictive of online buying impulsiveness. Middle level trait of value consciousness is mediating the effect of conscientiousness and negatively associated with the dependent variable.
\end{abstract}

Index Terms-Online buying impulsiveness, trait theory, $3 \mathrm{M}$ model

\section{INTRODUCTION}

Over the past decade, e-commerce has flourished and enjoyed a growth rate unrivaled by the traditional retail business. According to a report released by Taiwan's Institute for Information Industry, domestic e-commerce reached NT\$ 365 billion in 2012, a growth rate of $28.5 \%$ compared to the revenue of previous year. As more and more consumers turn to the Web as an indispensable source of price and products/brands information, the future of e-commerce seems even more promising. Therefore, studies on consumer behavior online are of great importance for both academic and practical researches.

One of the underdeveloped areas in online consumer research is impulse buying behavior. It is widely accepted that rational shopping model could not explain the whole spectrum of people's shopping motivations. In a more enjoyable shopping environment and with increased disposal incomes, consumers tend to shop more impulsively [1]. Moreover, impulse buying would be higher online compared to store shopping due to the normal evaluations of consumers are less of an inhibited factor [2].

As to the determinants of consumers' online behavior, demographics variables and more mutable personal factors like individual attitudes and personal perceptions have been frequently studied, personality variables like traits, on the other hand, have been under-investigated [3]. Since personality studies have long been an important research tool for examining human behavior [4] and trait-factor theory became the primary basis of marketing personality research [5], some personality traits related to online buying impulsiveness will be examined in this study.

The hierarchical approach will be employed in this research, which means, personality traits are interrelated hierarchically and classified by the degree to which they pervade behavior [6]. Traits of variety seeking and value consciousness are proposed to be two of the antecedents of

Manuscript received November 10, 2013; revised January 9, 2014.

Tsai Chen is with the Department of Communication, Fo Guang University, Yilan County, ROC (e-mail: tchen@mail.fgu.edu.tw).

Ming Chang Lee is with the Department of Management, Fo Guang University, Yilan County, ROC (e-mail: 1mj0055@gmail.com). online buying impulsiveness in the study. At the same time, the relationships between the two traits and more 'broad' personality dispositions will be also subjected to empirical test.

\section{THEORETICAL BACKGROUND AND HyPOTHESES}

\section{A. Trait Hierarchy}

A trait is a temporally stable, cross-situational individual difference. Personality traits refer to broad behavioral consistencies in the conduct of people [7] and form the structural basis of individual differences. Allport, one of the founding figures of personality psychology, has taken the viewpoint of three-level personality hierarchy [6]. At the highest level of pervasiveness are the traits known as cardinal dispositions. A trait like "Machiavellianism" dominates an individual's entire life. At the next level are central dispositions like compliance or compulsiveness. The last level of traits, secondary dispositions, are dispositions operant only in limited setting or roles.

John C. Mowen subsequently proposed a four-level hierarchy of traits: the elemental, compound, situational, and surface traits [8]. The major purpose of employing his Meta-Theoretic Model of Motivation and Personality (3M Model) is to identify predictive traits at each level in the personality hierarchy of certain consumer behavior as well their causal relations. In the $3 \mathrm{M}$, it is proposed that the elemental traits provide the broadest reference point for evaluating the outcomes of behavior. Thus, Mowen adopted the so called Big Five or Five-Factor Model (openness to experience, agreeableness, introversion, conscientiousness, and neuroticism) as a subset of the elemental traits and proposed need for arousal, need for material, and physical/body needs as another three basic traits [8]. Schneider and Vogt use 3M model of motivation and personality provided an organizing framework to explain the psychological roots of adventure tourism behavior [9].

\section{B. Online Buying Impulsiveness as Surface Trait}

Consumer researchers have for decades strived to find a better definition for impulse purchase. One major influence on an impulse purchase is the individual's internal differences with regard to impulsive acts. Impulsivity as a personality trait has been studied extensively by psychologists. Rook and Fisher therefore conceptualized an individual's impulse buying tendency as a consumer trait and defined buying impulsiveness as buying "spontaneously, unreflectively, immediately, and kinetically" [2]. Those with a higher impulsive buying tendency, tend to purchase more on impulse.

In an online shopping context, impulse purchase behaviors have been seldom investigated. Some studies that included 
buying impulsiveness have regarded impulsivity as only one of the variables that can influence the online purchasing intention [10], [11]. To gain a better understanding of online impulse buying, this study proposes online buying impulsiveness as the surface trait. Category-Specific surface traits delineate the programs of behavior that individuals run in order to complete tasks. These traits occur as a result of person, situation, and product category interactions [8]. Because surface traits measure enduring dispositions to display specific behavior patterns, they are highly predictive of outcome variables.

\section{Variety Seeking Tendency and Value Consciousness as Situational Traits}

The primary use of the Internet (other than e-mail) is for information retrieval. The ability to collect product information and make comparisons between the different product offerings from different providers is often viewed as one of the main competitive challenges for e-shopping [12]. Online shoppers appear to be attracted to the ease with which they can find information on the Internet, including the detailed product information available and the variety of choices offered [13]. Variety seeking and bargain hunting behaviors can be thus seen as two of the main reasons why consumers shop online.

From the psychological perspective, two personality traits are to explain the above mentioned behavior tendencies. According to the basic notion of Optimum Stimulation Level theories [14], every individual has an ideal level of stimulation. To attain a satisfactory level of stimulation, a person may engage in exploration of the environment. Consumers feel bored with routine purchase may complicate the buying process with variety-seeking behavior, in order to obtaining an optimal level of stimulation [15]. However, variety in itself can be satisfying. Individuals are believed to differ in their intrinsic desire for variety. This internal variety seeking tendency is assumed to be an important consumer characteristic, i.e., a rather constant personality trait [16].

Consumers are using online search to compare price and quality and to find better deals. Though bargain hunting is a common practice in online shopping, deal prone behavior cannot be fully explained without digging deep into underlining characteristic differences of individual consumers. Value consciousness was conceptualized as a personality trait [17]. It was introduced as a distinct psychological construct antecedent of deal prone behavior like coupon proneness [17]. Situational traits, according to Mowen's classification, are the unidemensional predispositions to behavior within a general situational context [8]. They result from the joint effects of elemental traits, compound traits, and the situational context. Because people express a disposition to be value conscious within the general context of purchasing goods and services, this trait is therefore placed at situational trait level.

$3 \mathrm{M}$ Model is employed to investigate personality traits within elemental and situational level predictive of online buying impulsiveness [8]. Since this research is exploratory in nature, a more parsimonious model is desirable, compound traits will therefore not be studied. Moreover, need body resources, one of the eight elemental traits, will not be developed hypothetical relationship of any kind.

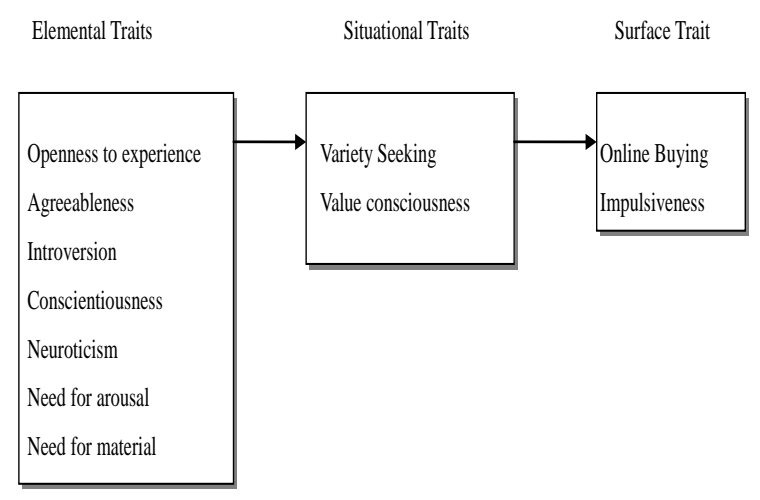

Fig. 1. Proposed research framework.

It is assumed that the effects of all seven elemental traits will be full mediated by situational traits, which in turn, affect the dependent variable. Fig. 1 illustrates the proposed research framework for this study.

Therefore, eight hypotheses are proposed as Fig. 2.

$\mathrm{H}_{1 \mathrm{a}}$ Openness to experience will be positively associated with variety seeking tendency.

$\mathrm{H}_{1 \mathrm{~b}}$ Agreeableness will be positively associated with variety seeking tendency.

$\mathrm{H}_{1 \mathrm{c}}$ Introversion will be negatively associated with variety seeking tendency.

$\mathrm{H}_{1 \mathrm{~d}}$ Need for arousal will be positively associated with variety seeking tendency.

$\mathrm{H}_{2 \mathrm{a}}$ Conscientiousness will be positively associated with value consciousness.

$\mathrm{H}_{2 \mathrm{~b}}$ Neuroticism will be positively associated with value consciousness.

$\mathrm{H}_{2 \mathrm{c}}$ Need for material will be negatively associated with value consciousness.

$\mathrm{H}_{3}$ Variety seeking tendency will be positively associated with online buying impulsiveness.

$\mathrm{H}_{4}$ Value consciousness will be negatively associated with online buying impulsiveness.

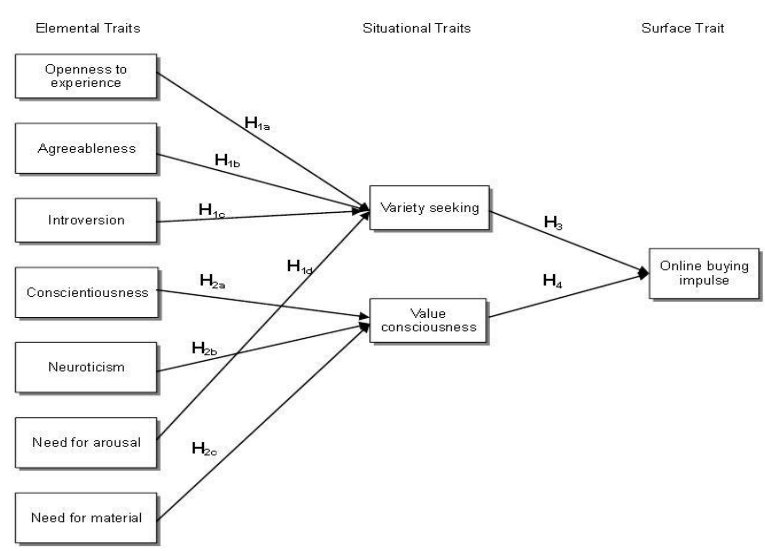

Fig. 2. Research model of this study.

\section{MATHODS}

Both online and paper-based surveys were conducted to gather the convenience sample for this study. The 
questionnaire was posted on the www.my3q.com, one of the leading academic online survey websites in Taiwan, and announced broadly on the Internet. At the same time, traditional paper-based questionnaires were disseminated through friends, colleagues, and fellow students, in order to diversify the sources of sample.

By the cut-off date, a convenience sample with the sample size of 540 responses was collected. Among the 540 responses received, 13 were discarded as incomplete, with 527 usable responses. Since there were no significant differences concerning independent variables measured between the online and paper-based sources of samples, the samples were combined for further analysis.

The major characteristics of the 527 subjects are described in Table I. They are gendered in female somewhat more than in male (Female, 65.1\%), a little more than half is in the age ranging 20 30 (52\%), higher educated (university, 60.2\%), almost $80 \%$ with monthly disposal income lower than NT\$ 20,000, and rather heavy users of the Web, $48 \%$ of surveyed used the Web 3 hrs. or more a day in average. The sample characteristics adequately reflect the population of Web shoppers to a large extent.

\section{A. Measures}

TABLE I: DEMOGRAPHIC PROFILE OF THE SAMPLE

\begin{tabular}{|c|c|c|c|}
\hline Variable & Categories & Number & Percentage $\%$ \\
\hline \multirow[t]{5}{*}{ Daily Web Usage } & Less than $1 \mathrm{hr}$. & 40 & 7.6 \\
\hline & $1 \sim 2$ & 128 & 24.3 \\
\hline & $2 \sim 3$ & 106 & 20.1 \\
\hline & $3 \sim 4$ & 57 & 10.8 \\
\hline & More than 4 hrs. & 196 & 37.2 \\
\hline Online Shopping Frequencies & 0 & 31 & 5.9 \\
\hline \multirow[t]{4}{*}{ over Last 12 Months } & $1 \sim 3$ & 261 & 49.5 \\
\hline & $4 \sim 6$ & 128 & 24.3 \\
\hline & $7 \sim 9$ & 48 & 9.1 \\
\hline & $10+$ & 59 & 11.2 \\
\hline \multirow[t]{2}{*}{ Gender } & Female & 343 & 65.1 \\
\hline & Male & 184 & 34.9 \\
\hline \multirow[t]{5}{*}{ Age } & $19-$ & 43 & 8.2 \\
\hline & $20 \sim 30$ & 274 & 52.0 \\
\hline & $31 \sim 40$ & 139 & 26.4 \\
\hline & $41 \sim 50$ & 51 & 9.7 \\
\hline & $51+$ & 20 & 3.8 \\
\hline \multirow[t]{5}{*}{ Education } & Middle School or less & 2 & 0.4 \\
\hline & High School & 39 & 7.4 \\
\hline & Professional School & 115 & 21.8 \\
\hline & University & 317 & 60.2 \\
\hline & Graduate School & 54 & 10.2 \\
\hline \multirow[t]{7}{*}{ Disposal Income (NT \$) } & 5,000 or less & 127 & 24.1 \\
\hline & $5,000 \sim 10,000$ & 143 & 27.1 \\
\hline & $10,000 \sim 20,000$ & 148 & 28.1 \\
\hline & $20,000 \sim 30,000$ & 51 & 9.7 \\
\hline & $30,000 \sim 40,000$ & 28 & 5.3 \\
\hline & $40,000 \sim 50,000$ & 21 & 4.0 \\
\hline & 50,000 or more & 9 & 1.7 \\
\hline
\end{tabular}

Measuring instruments were adapted from pre-validated measures in marketing and personality research. Items for measuring elemental traits (openness to experience, introversion, conscientiousness, need for arousal, and need for material resources) were adapted from scales developed by [8]. Variety seeking tendency was measured using an instrument taken from Baumgartner and Steenkamp [18], Value consciousness from Lichtenstein, Netemeyer, and
Burton [17], while online buying impulsiveness, the surface trait, was adapted from Weun, Jones, and Beatty [19]. Items were measured using a five-point Likert scale with anchors ranging from strongly disagree (1) to strongly agree (5).

Inter-correlations, means, and standard deviations of all constructs are tabulated below in Table II.

TABLE II: INTER-CORRELATIONS, MEANS, AND STANDARD DEVIATIONS OF CONSTRUCTS

\begin{tabular}{|c|c|c|c|c|c|c|c|c|c|c|}
\hline & 1 & 2 & 3 & 4 & 5 & 6 & 7 & 8 & 9 & 10 \\
\hline Means & 3.58 & 4.08 & 3.17 & 3.58 & 2.72 & 3.15 & 2.9 & 3.4 & 3.83 & 2.5 \\
\hline S. D. & 0.69 & 0.62 & 0.83 & 0.68 & 0.85 & 0.76 & 0.83 & 0.57 & 0.6 & 0.71 \\
\hline $1.0 \mathrm{P}$ & 1 & & & & & & & & & \\
\hline 2.AG & $0.20 * *$ & 1 & & & & & & & & \\
\hline 3.IN & $-0.13 * *$ & $0.12 * *$ & 1 & & & & & & & \\
\hline $4 . \mathrm{CO}$ & $0.36 * *$ & $0.21 * *$ & -0.02 & 1 & & & & & & \\
\hline $5 . \mathrm{NU}$ & -0.08 & -0.07 & $0.25 * *$ & $-0.23 * *$ & 1 & & & & & \\
\hline $6 . \mathrm{NA}$ & $0.38 * *$ & 0.71 & -0.06 & 0.04 & $0.11 *$ & 1 & & & & \\
\hline $7 . \mathrm{NM}$ & $0.14 * *$ & $0.12 * *$ & 0.05 & 0.04 & $0.21 * *$ & $0.39 *$ & 1 & & & \\
\hline $8 . \mathrm{VS}$ & $0.48 * *$ & $0.10 *$ & $0.11 *$ & $0.16 * *$ & -0.02 & $0.62 * *$ & $0.32 * *$ & 1 & & \\
\hline $9 . \mathrm{VC}$ & $0.28 * *$ & $0.22 * *$ & 0.05 & $0.23 * *$ & -0.01 & $0.09 *$ & -0.03 & $0.19 * *$ & 1 & \\
\hline $10.0 \mathrm{I}$ & -0.07 & $0.10 *$ & 0.05 & $-0.12 * *$ & $-0.12 * *$ & $0.13 * *$ & $0.22 * *$ & 0.02 & $0.16 * *$ & 1 \\
\hline
\end{tabular}

$\mathrm{OP}=$ openness to experience, $\mathrm{AG}=$ Agreeableness, $\mathrm{IN}=$ Introversion, $\mathrm{CO}=$ Conscientiousness, $\mathrm{NU}=$ Neuroticism, $\mathrm{NA}=\mathrm{Need}$ for arousal, $\mathrm{NM}=\mathrm{Need}$ for material, $\mathrm{VS}=$ Variety seeking, $\mathrm{VC}=$ Value consciousness, $\mathrm{OI}=\mathrm{Online}$ buying impulse

\section{RESUlts AND Discussion}

LISREL was used for data analysis. The data-analytic strategy and procedures adopted in this research follow the two-step approach recommendations of Anderson and Gerbing: measurement and structural models [20]. LISREL 8.5 is the software used to assess the models.

Confirmatory Factor Analysis (CFA) was applied to evaluate validity of the model. All indices fit nicely except CFI reaches 0.88 and GFI 0.84 , a little lower than commonly cited criteria of 0.9 [21]. However, as GFI higher 0.8 could be interpreted as reasonable fit [22], the proposed model provided an adequate fit.

As to the goodness-of-fit indices of the structural model, the value of $\chi^{2}$ is 2100.92 , degrees of freedom (d.f.) is 749 , $\chi^{2} /$ d.f. equals 2.804, less than 3.0. Root Mean Square Error of Approximation (RMSEA) is 0.059, lower than 0.08 level. CFI reaches 0.88 and GFI 0.84 .

Five of the nine structural parameters that describe the relationship between the factors were statistically significant. $\mathrm{H}_{1 \mathrm{a}}, \mathrm{H}_{1 \mathrm{~d}}, \mathrm{H}_{2 \mathrm{a}}$ and both $\mathrm{H}_{3}$ and $\mathrm{H}_{4}$ are supported. The results of the structural modeling analysis are presented in Fig. 3.

Although both situational traits, variety seeking and value consciousness, are significantly related to online buying impulsiveness with expected directions, the explanatory power of the proposed model is disappointing. $\mathrm{R}^{2}$ is only 0.06 . Therefore, modifications to the proposed model were made. Additional model respecifications in the form of new path 
links from elemental traits to online buying impulsiveness were analyzed through modified model.

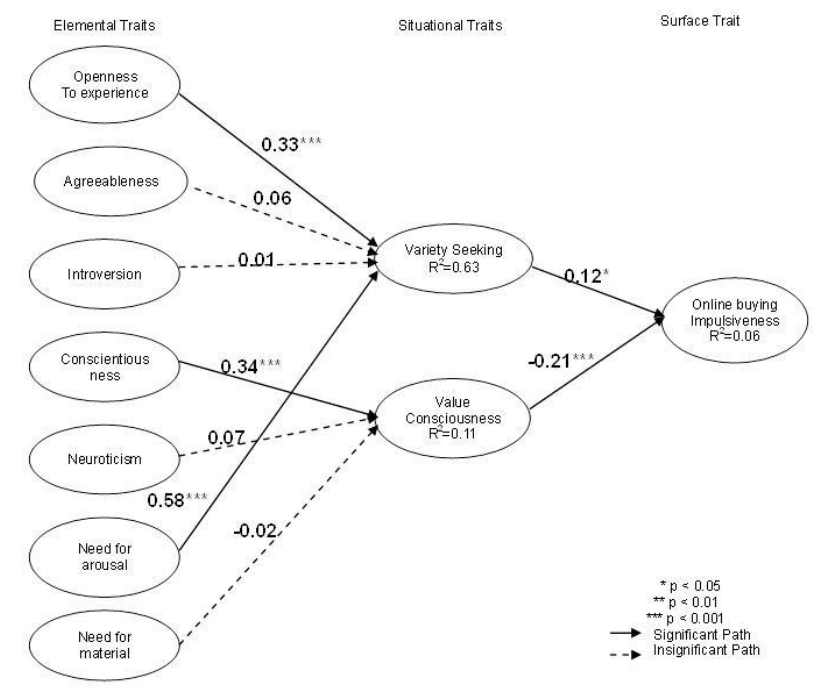

Fig. 3. Results of structural modeling analysis.

The value of $\chi^{2}$ of the modified model is 2039.47, degrees of freedom (d.f.) is $742, \chi^{2} /$ d.f. equals 2.740 . RMSEA is 0.058 . CFI reaches 0.89 and GFI 0.84 .

Fig. 4 presented the results of structural modeling analysis of the modified model. The relationships between elemental traits and situational traits remained basically the same. Openness to experience and need for arousal both significantly related to variety seeking and conscientiousness to value consciousness at 0.001 level. Value consciousness is still negatively associated with online buying impulsiveness at 0.001 levels, but the relationship of variety seeking tendency no longer exists. As to the direct effects of elemental traits to surface trait, agreeableness is significantly related at 0.01 levels, and need for arousal and need for material are significantly at the level of 0.05 and 0.001 respectively.

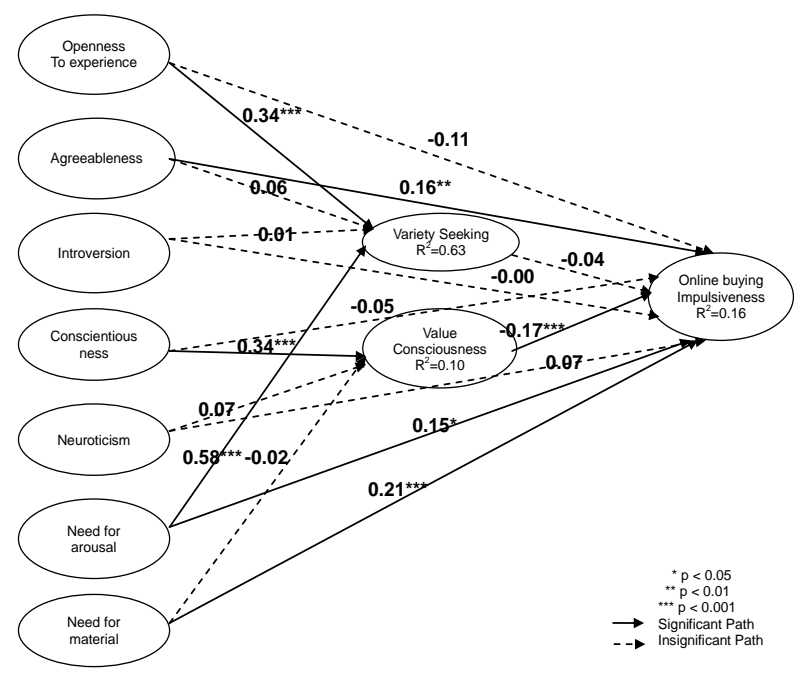

Fig. 4. Results of structural modeling analysis of modified model.

The explanatory power of the modified model seemed greatly improved. $\mathrm{R}^{2}$ of dependent variable reached 0.16 compared to 0.06 in the original model. Therefore, a partial mediated model proved to fit the data better than the first one.

\section{CONCLUSION}

The primary finding of this research is that a set of important related trait factors tend to be associated with a consumer's buying impulsiveness online. Value consciousness is negatively related to online buying impulsiveness as this study proposed and positively related to conscientiousness. Conscientiousness, referring to an organized, orderly, and efficient carrying out of tasks, can be also a useful trait for predicting the tendency to carry out purchase tasks efficiently.

As modified model revealed, agreeableness, need for arousal, and need for material are predictive of online buying impulsiveness. This study confirmed the materialistic dimension of the impulse buyer, who had higher materialism scores as well as higher scores on impulse buying [23]. The association of buying impulsiveness and need for arousal is in accordance with the general arousal theory proposed by Eysenck [24], that an individual's level of impulsiveness is inversely proportional to level of arousal, suggesting impulse people may be particularly "absorptive" to stimuli in a shopping environment [25]. Agreeableness is a tendency to be pleasant and accommodating in social situation, a trait domain comprised of facet traits like trust. It is reasonable to believe that more agreeable consumers may less mistrust online vendors compared to those more cautious ones, who would inhibit their buying urge.

Variety seeking tendency, though conceptually categorized in this study as situational trait, is proved to be related but not antecedent variable of online buying impulsiveness. Both variables may share the same psychological origin like impulse-sensation seeking (ImpSS) [26] and/or level of arousal [24]. Therefore, they belong to different dimensions of a broad personality trait.

It is widely accepted that the self-selection issue posed a problem in the questionnaire survey process and is a special methodological concern. It is especially true when we conduct any consumer behavior research because there is no general online shoppers" "population" can be identified.

Future studies may include the measurement of actual impulse buying behavior to validate the model. Samples can be selected from shopping websites and e-surveys conducted right after the transaction is completed or abandoned. Potential factors besides the constructs proposed by this study that may be significant in predicting impulse buying are also worthy of future investigating.

\section{REFERENCES}

[1] S. E. Beatty and M. E. Ferrell, "Impulse buying: modeling its precursors," Journal of Retailing, vol. 74, no. 2, pp. 169-191, 1998.

[2] D. W. Rook and R. J. Fisher, "Trait and normative aspects of impulsive buying behavior," Journal of Consumer Research, vol. 22, no. 3, pp. 305-313, 1995.

[3] C. Cheung, G. Chan, and M. Limayem, "A critical review of online consumer behavior: Empirical research," Journal of Electronic Commerce in Organizations, vol. 3, no. 4, pp. 1-19, 2005.

[4] H. H. Kassarjian, "Personality and consumer behavior: A review," Journal of Marketing Research, vol. 8, no. 4, pp. 409-418, 1971. 
[5] R. D. Blackwell, P. W. Miniard, and J. F. Engel, Consumer Behavior, $9^{\text {th }}$ ed. Mason, OH: South-Western.

[6] G. W. Allport, Pattern and Growth in Personality, NY: Holt, Rinehart, and Winston, Inc. 1961.

[7] L. A. Pervin, The Science of Personality, New York: Wiley, 1996.

[8] J. C. Mowen, The 3M Model of Motivation and Personality- Theory and Empirical Applications to Consumer Behavior, Norwell, MA: Kluwer Academic Publishers, 2000.

[9] P. P. Schneider and C. A. Vogt, "Applying the 3M model of personality and motivation to adventure travelers," Journal of Travel Research, vol. 51, no. 6, pp. 704-716, 2012.

[10] N. Donthu and A. Garcia, "The internet shopper," Journal of Advertising Research, vol. 39, no. 3, pp. 52-58, 1999.

[11] X. V. Zhang, R. Prybutok, and C. E. Koh, "The role of impulsiveness in a TAM-Based online purchasing behavior model," Information Resources Management Journal, vol. 19, no. 2, pp. 54-68, 2006.

[12] J. Rowley, "Product search in E-Shopping: A review and research propositions," Journal of Consumer Marketing, vol. 17, no. 1, pp. 20-35, 2000.

[13] M. R. Ward and M. J. Lee, "Internet shopping, consumer search and product branding," Journal of Product and Brand Management, vol. 9 , no. 1 , pp. 6-20, 2000.

[14] M. Zuckerman, Sensation Seeking: Beyond the Optimal Level of Arousal, Hillsdale, NJ: Erlbaum, 1979.

[15] J. E. M. Steenkamp and H. Baumgartner, "The role of optimum stimulation level in exploratory consumer behavior," Journal of Consumer Research, vol. 19, no. 3, pp. 434-448, 1992

[16] H. C. M. V. Trijp and J. E. M. Steenkamp, “Consumers' variety seeking tendencies with respect to foods: Measurement and managerial implications," European Review of Agricultural Economics, vol. 19, no. 2, pp. 181-195, 1992.

[17] D. R. Lichtenstein, R. G. Netemeyer, and S. Burton, "Distinguishing coupon proneness from value consciousness: An acquisition transaction utility theory perspective," Journal of Marketing, vol. 54, pp. 54-67, 1990.

[18] H. Baumgartner and J. E. M. Steenkamp, "Exploratory consumer buying behavior: conceptualization and measurement," International Journal of Research in Marketing, vol. 13, no. 2, pp. 121-137, 1996.

[19] S. Weun, M. A. Jones, and S. B. Beatty, "The development and validation of the impulse buying tendency scale," Psychological Reports, vol. 82, pp. 1123-1133, 1988.
[20] J. C. Anderson and D. W. Gerbing, "Structural equation modeling in practice: A review and recommended two-step approach," Psychological Bulletin, vol. 103, no. 2, pp. 411-423, 1988.

[21] J. F. Hair, R. E. Anderson, R. E. Tatham, and W. C. Black Multivariate Data Analysis, $5^{\text {th }}$ ed., Upper Saddle River, NJ: Prentice Hall, 1998.

[22] W. J. Doll, W. Xia, and G. Torkzadeh, "A confirmation of factor analysis of the end user computer satisfaction instrument," MIS Quarterly, vol. 18, no. 4, pp. 453-461, 1994.

[23] J. D. Troisi, A. N. Christopher, and P. Marek, "Materialism and money spending disposition as predictors of economic and personality variables," North American Journal of Psychology, vol. 8, no. 3, pp. 421-436, 2006.

[24] H. J. Eysenck, , "The Nature of Impulsivity," in The Impulse Client: Theory, Research, and Treatment, W. G. Cown, J. L. Johnson, and M. B. Shure eds., Washington, DC: American Psychological Association, 1993, pp. 57-70.

[25] S. Youn and R. J. Faber, "Impulse buying: its relation to personality traits and cues," Advances in Consumer Research, vol. 27, pp. 179-185, 2000.

[26] M. Zuckerman, "Sensation Seeking and Impulsivity: A Marriage of Traits Made in Biology," in The Impulse Client: Theory, Research, and Treatment, W. G. McCown, J. L. Johnson, and M. B. Shure eds., Washington, DC: American Psychological Association, 1993, pp 71-92.

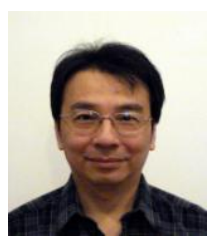

Tsai Chen is an associate professor with Department of Communication at Fo Guang University. He has a Ph.D. degree in the field of marketing from the National Taipei University in Taipei, ROC. His research focuses on advertising management.

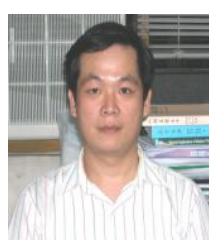

Ming Chang Lee is an assistant professor with Department of Management at Fo Guang University. He has a Ph.D. degree in the field of marketing from the National Taipei University in Taipei, ROC. His research focuses on service marketing, customer satisfaction and financial management. 